\title{
Uncovering the effects of prior founding experience of entrepreneurs on early board selection
}

\author{
Laura Gasiorowski
}

Alfred Lerner College of Business and Economics, University of Delaware, Newark, Delaware, USA, and

\author{
Ahreum Lee \\ School of Business, State University of New York at Oswego, \\ Oswego, New York, USA
}

\begin{abstract}
Purpose - This study aims to show what type of directors founders (or entrepreneurs) first appoint to the board and how these appointments differ across experienced and novice entrepreneurs.

Design/methodology/approach - The sample consists of the human capital of board members in 443 new ventures in the computer software and information technology industries between 2000 and 2014. The hypotheses were tested using tobit regression.

Findings - The findings in this study reveal that compared to novice entrepreneurs, experienced entrepreneurs tend to appoint early boards with greater human capital (entrepreneurial, technical/scientific and industry-specific) and with greater functional diversity. In contrast, novice entrepreneurs tend to appoint early boards with greater finance and director experience.

Originality/value - The value of this research lies in filling the gap in the current literature by comparing the board appointment/selection behavior of novice and experienced entrepreneurs, which is relatively underexplored.
\end{abstract}

Keywords Board of directors, Resources, Novice and experienced entrepreneurs,

Prior founding experience

Paper type Research paper

\section{Introduction}

The acquisition of resources is crucial to the survival and growth of new ventures (Lichtenstein and Brush, 2001; Robinson and Stubberud, 2009). Studies find that having the right mix of human, financial and social capital is positively associated with outcomes such as profitability, survival, IPOs and venture capital funding (Beckman et al., 2007; Hsu, 2007; Park and Park, 2018; Udimal et al., 2019). However, the acquisition of resources poses a

(C) Laura Gasiorowski and Ahreum Lee. Published in Asia Pacific Journal of Innovation and Entrepreneurship. Published by Emerald Publishing Limited. This article is published under the Creative Commons Attribution (CC BY 4.0) licence. Anyone may reproduce, distribute, translate and create derivative works of this article (for both commercial and non-commercial purposes), subject to full attribution to the original publication and authors. The full terms of this licence maybe seen at http://creativecommons.org/licences/by/4.0/legalcode

Received 14 March 2020

Revised 2 June 2020 4 July 2020

15 August 2020

Accepted 5 September 2020 
considerable challenge for emerging ventures (Brush et al., 2001), and this becomes more severe for emerging high-tech ventures owing to the lack of legitimacy, the liability of smallness and the uncertain and dynamic environment in which ventures operate (Bradley et al., 2011).

Extant studies draw on resource dependence theory to enhance our understanding of how new ventures acquire critical resources to reduce environmental dependence, a significant vulnerability for new ventures (Aldrich and Ruef, 2006; De Prijcker et al., 2019). Focusing on the potential resource provision role of boards, studies have found that directors bring valuable human and social capital to new ventures and those resources lead to positive venture outcomes (Li et al., 2020 for review).

While the role and impact of boards on new venture outcomes have been extensively studied, how new ventures select directors to acquire resources is equally important but relatively understudied. Prior research shows that early venture board appointments tend to come from founder's decisions and networks (Balachandran et al, 2019), and one of the greatest sources of heterogeneity among founders is their prior founding experience (Ucbasaran et al., 2009). Relative to novices, experienced entrepreneurs tend to have more robust networks (Westhead et al., 2005) and greater knowledge and skills to develop a venture (Shane and Khurana, 2003). However, we still have a limited understanding of how prior founding experience impacts the directors appointed to early boards. As boards tend to be path-dependent and early appointments endure (Hillman and Dalziel, 2003), it is crucial to understand whether and how entrepreneurial experience impacts early board selection behavior.

The purpose of this study is to fill this gap by showing what type of directors founders (or entrepreneurs) first appointed to the board and how these appointments differ across experienced and novice entrepreneurs. We do this by investigating the human capital of board members in 443 new ventures in the computer software and information technology industries between 2000 and 2014. Building on resource dependence theory, we hypothesize that, relative to novice entrepreneurs, experienced entrepreneurs are more likely to appoint early boards with greater human capital (entrepreneurial, technical/scientific, industryspecific, marketing, finance and director) and with greater functional diversity. We find broad support for most dimensions of human capital.

Our contribution is, therefore, that we shed light on one of the mechanisms new ventures use to build and adapt resources, i.e. board of directors. Given the fact that new ventures inherently bear resource scarcity, the role of boards as resource providers is more critical. We also expand the work on new venture boards by examining prior founding experience as a key antecedent to board composition. Ucbasaran et al. (2003, p. 7) note that "relatively few studies have explicitly compared the behavior and attitudes reported by inexperienced novice entrepreneurs and experienced habitual entrepreneurs." Acknowledging this, we compare the board appointment/selection behavior of novice and experienced entrepreneurs, which, to the best of our knowledge, is one of the few attempts. In doing so, we answer a recent call for an examination of the antecedents of boards to understand why certain directors are appointed and how and why venture governance configurations emerge (Li et al., 2020; Garg and Furr, 2017).

\section{Theoretical background and hypothesis development}

Boards of directors in entrepreneurial firms

A growing stream of literature on entrepreneurship has recognized the importance of the board of directors in new ventures (Kim, 2018). Venture boards impact important major venture outcomes, such as IPO events, venture capital funding, innovation performance, growth and survival (Garg and Furr, 2017). While studies on the board of directors are 
predominantly guided by agency theory, which emphasizes boards' monitoring and controlling role, recent studies focused on boards in new ventures are skewed toward resource dependence theory and the board's role as resource providers (Garg and Furr, 2017). This is unsurprising given that small, early-stage entrepreneurial firms often have very limited resources, and the acquisition of such resources is crucial for long-term success (Lichtenstein and Brush, 2001; Garg and Furr, 2017). This becomes more problematic for young high-tech ventures, as they are confronted with an uncertain and dynamic environment in addition to a lack of internal resources and legitimacy (Bradley

Prior founding experience et al., 2011).

Resource dependence theory views the firm as an open system that is dependent on external organizations for the supply of strategic resources for survival (Pfeffer and Salancik, 1978). Such environmental dependence is considered a source of vulnerability (Aldrich and Ruef, 2006). Therefore, the survival and success of a firm is dependent on the firm's ability to minimize its dependency on the external environment (Pfeffer and Salancik, 1978). Managers can reduce environmental dependence through various actions and appointing boards, especially resource-rich directors, is one way to do so as boards can facilitate access to critical resources (Hillman et al., 2009).

Prior research shows that human capital, defined as skills and knowledge that individuals acquire through investments in schooling, on-the-job training and other types of experience (Becker, 1964), of entrepreneurial firms, is critical for their performance. The human capital of entrepreneurial firms increases their capability to discover and exploit business opportunities (Shane and Venkataraman, 2000) and implement planning and venture strategy (Baum et al., 2001), all of which contribute to positive outcomes.

Resources provided by boards can significantly impact venture outcomes. Directors can provide key social connections that affect the speed at which ventures develop alliance portfolios, which in turn affects the speed at which the venture hits revenue milestones (Beckman et al., 2014). Directors can also provide prestige or legitimacy to a new venture that can enhance IPO performance (Certo, 2003). Through various functional experiences, such as R\&D and marketing and sales experience, directors enhance venture outcomes such as the number of patent filings and/or the number of new products to market (Vandenbroucke et al., 2016). Overall, most extant studies building on resource dependence theory have found a positive role of boards in new ventures.

Given the importance of new venture boards, scholars have started to examine the antecedents to uncover why firms develop different board compositions and structures. Prior research has identified many factors that impact the configuration of the board, including firm-specific characteristics and the competitive environment (Li et al., 2020). Experience supplementing is also a key antecedent of board experience in entrepreneurial firms (Kor and Misangyi, 2008). Kor and Misangyi (2008) find that firms with lower levels of top management team industry experience tend to have boards with higher amounts of industry experience. We extend this line of inquiry to examine how prior entrepreneurial experience influences director selection.

\section{Experienced vs. novice entrepreneurs: differences in board selection}

Prior founding experience can be considered an element of entrepreneurship-specific human capital (Stuart and Abetti, 1990) and is, therefore, one of the key factors underlying the heterogeneity among entrepreneurs (Ucbasaran et al., 2009). It has informed many discussions related to entrepreneurship phenomena, such as the identification of new insights (Shane, 2000). Relative to novice, first-time entrepreneurs, experienced entrepreneurs have greater knowledge, 
assets and liabilities from their prior experience owning a business, which can impact their attitudes and behaviors in subsequent ventures (Westhead et al, 2005). Specifically, these differences can impact entrepreneurs' attitudes toward the types of directors they need and behaviors regarding which directors they appoint in forming their early boards.

\section{Board selection mechanisms: ability and attraction}

There are two key mechanisms through which prior entrepreneurial experience may impact board appointments: ability and attraction (Shane and Khurana, 2003; Hsu, 2007). First, experienced entrepreneurs may have greater abilities in developing a new venture (Shane and Khurana, 2003; Hsu, 2007). Shane and Khurana (2003) argue that experienced founders have not only mastered their own role but also the ability to structure the roles of others. Having experience in the role of founder endows the entrepreneur with knowledge of how to develop a new organization, including leading, hiring, attracting and retaining others (Ucbasaran et al.2006), as well as fostering innovation (Vaillant and Lafuente, 2019). Conversely, novices must learn and adapt to this new role over time, suggesting an early inability to structure a productive board of directors.

Founders with prior founding experience also tend to have greater networks and a greater reputation than their novice counterparts (Westhead et al., 2005). These advantages may allow experienced entrepreneurs to attract and retain more experienced executives (Westhead and Wright, 1998; Delmar and Shane, 2006). Particularly because new venture board appointments tend to come from the founder's network ties (Balachandran et al., 2019), having more robust networks would enable an experienced entrepreneur to attract more experienced directors than a novice. Hsu (2007) shows that entrepreneurs with more prior founding experience are more likely to receive $\mathrm{VC}$ funding through a direct network tie, which suggests that prior founding experience involves both a network benefit and a signal through which entrepreneurs can attract resourceproviders.

Because of these ability and attraction differences, we expect that experienced entrepreneurs will appoint more experienced (greater human capital) boards and more diverse boards than novice entrepreneurs. Prior research finds that experienced entrepreneurs are more likely to bring in additional partners in subsequent ventures (Westhead and Wright, 1998) and are more likely to emphasize the importance of needing more human capital resources from more sources (Westhead et al., 2005). Further, research suggests that productive and effective upper echelon inherently involves diversity (Beckman et al., 2007). In new ventures, research has found that greater functional diversity is associated with achieving positive outcomes and reaching venture milestones faster (Beckman and Burton, 2008; Beckman et al., 2007). New ventures require the full range of knowledge and abilities of multiple functions (R\&D, marketing, manufacturing, etc.) to build their organization (Beckman et al., 2007; Vandenbroucke et al., 2016). As experienced entrepreneurs should have greater ability in attracting talent and developing organizational structures, their venture's board of directors should reflect greater functional diversity. Thus:

H1. Relative to novice entrepreneurs, experienced entrepreneurs will appoint early boards with greater human capital (entrepreneurial, technical/scientific and industry-specific, marketing/sales, director and finance).

H2. Relative to novice entrepreneurs, experienced entrepreneurs will appoint early boards with greater functional diversity (Figure 1). 


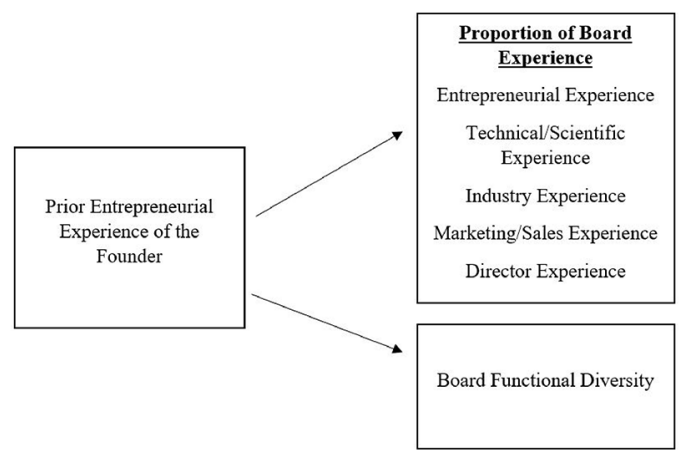

\section{Methodology}

To test our hypotheses, we use data on board of director experience from BoardEx and selfreported firm age and founder experience from firm websites, Crunchbase and VentureXpert.

Our sample consists of 443 new ventures (age 10 or less when they enter the sample) in the computer software and information technology industries from 2000 to 2014.

Founder prior experience is measured as a dummy variable. A value of " 1 " indicates that at least 1 founder had previously founded a venture. A value of " 0 " indicates no prior founding experience of any member of the founding team.

We categorize board experience into six functional domains based on prior research that has found certain types of experience to be crucial to new ventures: technical/scientific, entrepreneurial, finance, marketing/sales, industry-specific and director experience. Technical/scientific experience and marketing/sales experience are critical to new venture functions of innovation, product development and market performance (Beckman et al., 2007; Vandenbroucke et al., 2016). Entrepreneurial experience and finance experience are also critical to the development of new ventures (Beckman and Burton, 2008). Industryspecific experience on boards is beneficial to reducing the liability of newness in new ventures (Kor and Misangyi, 2008). Experience as a director has also been shown to positively impact high-technology firm growth (Kor and Sundaramurthy, 2009).

Following Beckman and Burton (2008), we coded the career histories of all directors to determine the nature of their prior experience. For instance, entrepreneurial experience was indicated if the role at a prior organization was listed as "Founder" and technical/scientific experience was coded if the role at a prior organization was listed as "Engineer", "R\&D", "Technical Lead", etc. This coding process allowed us to count the number of years that director held the role and add up all years of experience with a role in each functional area. We measure functional experience as a proportion. For each functional area, board experience is measured as the amount of collective years of functional experience on the board to all prior experience years of the board's current members.

While most diversity studies use either Blau's index or Shannon's index to capture board diversity, our data does not allow us to use these measures easily because the categories are not mutually exclusive. A director can have experience in several functional domains and, therefore, would be counted multiple times. Moreover, we are less interested in how experience is distributed across board members and more interested in whether there is a range of experience to draw on (regardless of how many different members have this experience). As such, we calculate a dummy variable for each experience type, which equals 1 if the board in that year has at least 1 director with that type of experience. We add the 
APJIE 14,3

dummy variables from all six experience types and divide by the total number of dimensions (6). We then left with a variable between 0 and 1 . A value of " 0 " indicates a board has none of the six dimensions of experience and a value of " 1 " indicates a board has the full range of six types of experience to draw on.

We include control variables that could possibly influence the relationship between types of entrepreneurs and board selection and, therefore, could confound our results. First, we control for venture age as to ensure that the identified effects are not the result of age-related processes (Vandenbroucke et al., 2016). We also include board size, as it is positively related to firm size (Yermack, 1996). We also control for average director age, as it may impact the experience level and cognitive abilities of directors (Kor and Misangyi, 2008). We also control for the location of the ventures as studies have found that location matters for entrepreneurs to attract valuable resources. For instance, De Prijcker et al. (2019) found that non-VC-backed ventures that are founded in states with lower availability of VC are more likely to relocate to VC-rich states such as California or Massachusetts.

We use a tobit estimator to account for two features of our data. First, it is not uncommon for a new venture to have no experience in certain domains, especially in very early stage firms that have very few board members. Thus, many observations will have values of zero. Second, our experience variables are also right truncated, as proportion variables cannot be more than $100 \%$. Thus, we needed an estimator that can account for both features of our dependent variable.

\section{Results}

Table 1 provides descriptive statistics for all variables. The average director age is around 53 years, with a range from 28 to 77 . Most directors that were under 35 were the founder or founding team members. These directors are excluded in the analysis of board composition, as we are interested in the experience of the directors they appoint. The average proportion of entrepreneurial experience on boards is about $3 \%$, whereas the average of proportion of director experience is high at $69 \%$. The occurrence of prior founding experience is low at about $6.5 \%$ of the ventures in our sample. We performed a correlation analysis and none of the correlations were high enough to warrant any concern about multicollinearity.

\begin{tabular}{lcccc}
\hline Variable & Mean & SD & Min & Max \\
\hline Dependent variables & & & & \\
Board entr exp & 0.036 & 0.089 & 0 & 0.75 \\
Board tech/sci exp & 0.095 & 0.155 & 0 & 1 \\
Board industry exp & 0.221 & 0.186 & 0 & 1 \\
Board director exp & 0.687 & 0.249 & 0 & 1 \\
Board finance exp & 0.103 & 0.149 & 0 & 1 \\
Board mktg/sales exp & 0.102 & 0.147 & 0 & 1 \\
Board diversity & 0.571 & 0.187 & 0 & \\
Independent variables & & & & 1 \\
Founder entr exp & 0.065 & 0.247 & 0 & 22 \\
Venture age & 12.208 & 5.513 & 0 & 4.34 \\
Board size & 6.087 & 2.301 & 1 & 1 \\
Avg director sge (log) & 3.680 & 1.086 & 0 & 2 \\
Location East USA & 0.329 & 0.470 & 0 & 0 \\
Location Central USA & 0.137 & 0.344 & 1 & \\
Industry & 1.183 & 0.386 & &
\end{tabular}

Table 1.

Descriptive statistics 
The results from tobit regressions are presented in Tables 2 and 3. Table 2 shows the results of testing the effect of prior founding experience on the proportion of experience in the following six areas: prior entrepreneurial, technical/scientific, industry-specific, finance, marketing/sales and director experience. In line with our hypotheses, we expect that prior founding experience will be positively associated with greater experience in all domains owing to a greater ability to build effective boards and attract more experienced directors to appoint.

Models 2, 4 and 6 of Table 2 show that having prior founding experience is positively and

Prior founding experience

269 significantly associated with having a greater proportion of entrepreneurial, technical/ scientific and industry-specific experience on the board. To put this in perspective, the marginal effects indicate that, holding all other variables at their mean values, a venture with an experienced founder will have $28 \%$ entrepreneurial experience on the board and $24 \%$ industry experience (compared to $22 \%$ for both entrepreneurial and industry for ventures founded by a novice). Technical/scientific experience also varies by $6 \%$ between experienced and novice founders.

Although the effects were only marginally significant $(\phi<0.1)$, prior founding experience is positively related to a greater proportion of marketing/sales experience on the board and negatively related to finance experience (Models 8 and 10 of Table 2).

In Model 12 of Table 2, contrary to what we predicted, prior founding experience is negatively and significantly related to the proportion of prior director experience on the board. In terms of marginal effects, we find that, holding all other variables at their mean values, a venture with an experienced founder has about $60 \%$ prior director experience, whereas a venture with a novice founder has about $72 \%$.

Overall, these results provide some support for H1. Experienced entrepreneurs have greater proportions of entrepreneurial, technical and industry-specific experience on the board. However, we find marginal support for experienced entrepreneurs having more marketing/sales experience and finance experience on the board. In addition, we find that experienced entrepreneurs have significantly less director experience on the board.

In Model 2 of Table 3, we test our prediction that prior founding experience is positively related to board diversity. The coefficient on prior founding experience is positive and significant, providing support for H2. In terms of marginal effects, holding all other variables at mean values, a venture with an experienced founder has $61 \%$ diversity, while that of a novice has about $58 \%$ diversity.

\section{Discussion}

This paper presents findings that suggest key differences in how experienced and novice entrepreneurs assemble their early board of directors. Our analysis shows that experienced entrepreneurs tend to appoint more experienced directors than novice entrepreneurs. Specifically, they assemble boards that have a greater proportion of entrepreneurial experience, technical/scientific experience, industry experience and marketing/sales experience than novice founders. Contrary to our hypotheses, novices tend to assemble boards that have a greater proportion of prior director experience and finance/banking experience (although only marginally significant). Our results seem to suggest that novices perceive professional directors and finance/banking experience of directors to be the most crucial resources for developing their new ventures.

There are some likely explanations for our results. One plausible explanation would be differences in how entrepreneurs collect and process information. Westhead et al. (2005) find that novice entrepreneurs used significantly fewer sources of information in the opportunity identification process compared to experienced entrepreneurs. Inexperienced entrepreneurs 
$\underset{14,3}{\text { APJIE }}$

270
Table 2.

Regression results: proportion of board experience

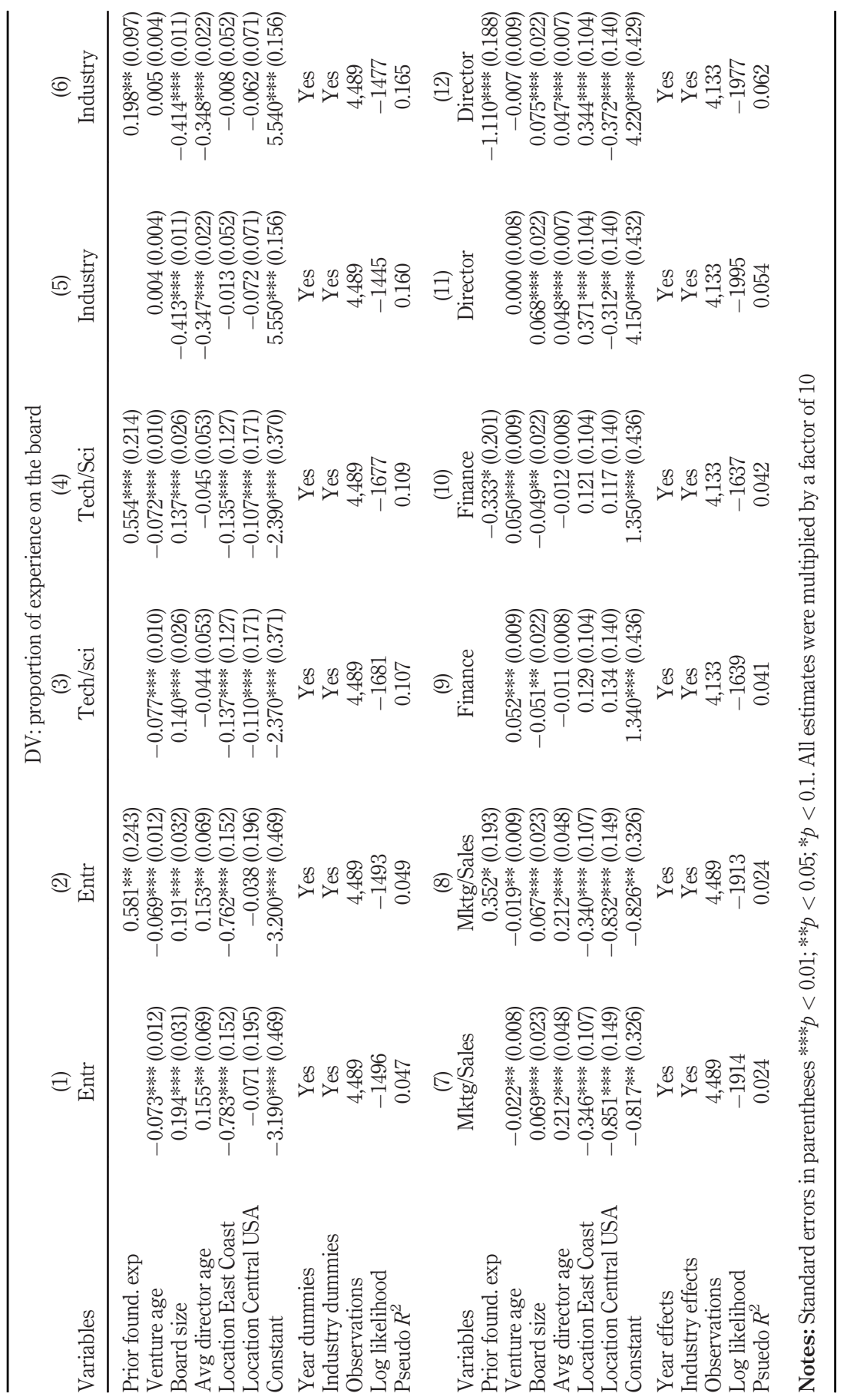




\begin{tabular}{|c|c|c|c|}
\hline Variables & $\begin{array}{c}(1) \\
\text { Diversity }\end{array}$ & $\begin{array}{c}(2) \\
\text { Diversity }\end{array}$ & experience \\
\hline \multicolumn{2}{|l|}{ Founder prior entr experience } & $0.280 * *(0.114)$ & \\
\hline Venture age & $-0.009 *(0.005)$ & $-0.007(0.005)$ & \\
\hline Board size & $0.235 * * * *(0.012)$ & $0.234 * * *(0.012)$ & \\
\hline Avg director age & $0.146 * * *(0.026)$ & $0.146^{* * * *}(0.026)$ & \\
\hline Location East Coast & $-0.436 * * *(0.061)$ & $-0.429 * * *(0.061)$ & 271 \\
\hline \multirow{2}{*}{$\begin{array}{l}\text { Location Central USA } \\
\text { Constant }\end{array}$} & $\begin{array}{r}-0.469 * * * *(0.082) \\
4210 * * *(0181)\end{array}$ & \multirow{2}{*}{$\begin{array}{r}-0.454 * * *(0.082) \\
4.210 * * *(0.181)\end{array}$} & \\
\hline & $4.210^{* * * *}(0.181)$ & & \\
\hline $\begin{array}{l}\text { Year dummies } \\
\text { Industry dummies }\end{array}$ & $\begin{array}{l}\text { Yes } \\
\text { Yes }\end{array}$ & $\begin{array}{l}\text { Yes } \\
\text { Yes }\end{array}$ & \\
\hline Observations & $\begin{array}{c}\text { res } \\
4.489\end{array}$ & 4,489 & \\
\hline Log likelihood & -1054 & -1057 & \\
\hline Pseudo $\mathrm{R}^{2}$ & 0.4439 & 0.4478 & $\begin{array}{l}\text { Regression results: } \\
\text { diversity of }\end{array}$ \\
\hline \multicolumn{3}{|c|}{$\begin{array}{l}\text { Notes: Standard errors in parentheses } * * * p<0.01 ; * * p<0.05 ; * p<0.1 \text {. All estimates were multiplied by a } \\
\text { factor of } 10\end{array}$} & $\begin{array}{r}\text { experience on the } \\
\text { board }\end{array}$ \\
\hline
\end{tabular}

are found to lack frameworks for processing information and may be overwhelmed by too much information (Westhead et al., 2005). Thus, novices may focus on a narrower range of problems - specifically finance and director experience. Another plausible explanation may be that novices are trying to overcome their inexperience by "professionalizing" their board, something that is typically not done until ventures reach certain stages and hit certain milestones (Hellmann and Puri, 2002). For experienced entrepreneurs, their tendency to have greater specific human capital on the board may be the result of being generalists or jacksof-all-trades.

In addition, we show that experienced entrepreneurs assemble boards with greater functional diversity. New venture boards of firms founded by experienced entrepreneurs had greater representation of the six types of prior experience, which seems to suggest that prior founding experience may enable the assembly of more experienced and diverse early boards through an enhanced ability to develop an organization or attract more experienced and more diverse directors.

\section{Conclusions}

Our study has important implications for both academia and practitioners. For academia, our study contributes to the current entrepreneurship literature, which has extensively studied boards in new ventures but has largely neglected the mechanism of board selection in these ventures. Specifically, we show that prior entrepreneurial experience impacts early board selection, highlighting an important antecedent of board composition and extending our understanding of how differences in prior experience impact new ventures. Given the pathdependent nature of boards (Hillman and Dalziel, 2003), this line of research has great implications for high tech entrepreneurs, especially novice entrepreneurs. As securing critical resources is important for early startups' survival and success, it is of utmost importance for novices to be aware and take action to close the gap on board human capital deficits. By doing so, novice entrepreneurs may increase the chance of their ventures' survival and success.

One future avenue to explore is to investigate why novice founders seem to focus on finance experience and professional directors to the detriment of the other dimensions of experience when assembling a board. Although we provide some plausible explanations on 
it, more studies are warranted to enhance our understanding of the differences in board assembly between novice and experienced entrepreneurs. Another avenue to explore is to see whether these differences in assembling boards with specific vs general human capital can be associated with venture performance differences or with the extent of founders' generalist backgrounds. Future studies could further explore whether and how these differences impact other dimensions of capital, such as social, intellectual and financial. Finally, our study may be replicated to other industries and/or other countries. As our research context was on ventures in high-technology industries in the USA, our findings may not be generalized to other industries such as low-tech industries and/or other countries which may have different institutional context.

\section{References}

Aldrich, H. and Ruef, M. (2006), Organizations Evolving, 2nd ed., Sage, Thousand Oaks, CA.

Balachandran, C., Wennberg, K. and Uman, T. (2019), "National culture diversity in new venture boards: the role of founders' relational demography”, Strategic Entrepreneurship Journal, Vol. 13 No. 3, pp. 410-434.

Baum, J.R., Locke, E.A. and Smith, K.G. (2001), "A multidimensional model of venture growth", Academy of Management Journal, Vol. 44 No. 2, pp. 292-303.

Becker, G.S. (1964), Human Capital and the Personal Distribution of Income: An Analytical Approach (No. 1), Institute of Public Administration.

Beckman, C.M. and Burton, M.D. (2008), "Founding the future: path dependence in the evolution of top management teams from founding to IPO", Organization Science, Vol. 19 No. 1, pp. 3-24.

Beckman, C.M., Burton, M.D. and O'Reilly, C. (2007), "Early teams: the impact of team demography on VC financing and going public", Journal of Business Venturing, Vol. 22 No. 2, pp. 147-173.

Beckman, C.M., Schoonhoven, C.B., Rottner, R.M. and Kim, S.J. (2014), "Relational pluralism in de novo organizations: boards of directors as bridges or barriers to diverse alliance portfolios?", Academy of Management Journal, Vol. 57 No. 2, pp. 460-483.

Bradley, S.W., Aldrich, H., Shepherd, D.A. and Wiklund, J. (2011), "Resources, environmental change, and survival: Asymmetric paths of young independent and subsidiary organizations", Strategic Management Journal, Vol. 32 No. 5, pp. 486-509.

Brush, C.G., Greene, P.G. and Hart, M.M. (2001), "From initial idea to unique advantage: the entrepreneurial challenge of constructing a resource base", Academy of Management Perspectives, Vol. 15 No. 1, pp. 64-78.

Certo, S.T. (2003), "Influencing initial public offering investors with prestige: signaling with board structures", Academy of Management Review, Vol. 28 No. 3, pp. 432-446.

De Prijcker, S., Manigart, S., Collewaert, V. and Vanacker, T. (2019), "Relocation to get venture capital: a resource dependence perspective”, Entrepreneurship Theory and Practice, Vol. 43 No. 4, pp. 697-724.

Delmar, F. and Shane, S. (2006), "Does experience matter? The effect of founding team experience on the survival and sales of newly founded ventures", Strategic Organization, Vol. 4 No. 3, pp. 215-247.

Garg, S. and Furr, N. (2017), "Venture boards: past insights, future directions, and transition to public firm boards”, Strategic Entrepreneurship Journal, Vol. 11 No. 3, pp. 326-343.

Hellmann, T. and Puri, M. (2002), "Venture capital and the professionalization of start-up firms: empirical evidence", The Journal of Finance, Vol. 57 No. 1, pp. 169-197.

Hillman, A.J. and Dalziel, T. (2003), "Boards of directors and firm performance: integrating agency and resource dependence perspectives", Academy of Management Review, Vol. 28 No. 3, pp. 383-396.

Hillman, A.J., Withers, M.C. and Collins, B.J. (2009), "Resource dependence theory: a review”, Journal of Management, Vol. 35 No. 6, pp. 1404-1427. 
Hsu, D.H. (2007), "Experienced entrepreneurial founders, organizational capital, and venture capital funding", Research Policy, Vol. 36 No. 5, pp. 722-741.

Kim, S. (2018), "Domains and trends of entrepreneurship research", Management Review: An International Journal, Vol. 13 No. 1, pp. 65-90.

Kor, Y.Y. and Misangyi, V.F. (2008), 'Outside directors' industry-specific experience and firms' liability of newness", Strategic Management Journal, Vol. 29 No. 12, pp. 1345-1355.

Kor, Y.Y. and Sundaramurthy, C. (2009), "Experience-based human capital and social capital of outside directors", Journal of Management, Vol. 35 No. 4, pp. 981-1006.

Li, H., Terjesen, S. and Umans, T. (2020), "Corporate governance in entrepreneurial firms: a systematic review and research agenda", Small Business Economics, Vol. 54 No. 1, pp. 1-32.

Lichtenstein, B.M.B. and Brush, C.G. (2001), "How do 'resource bundles' develop and change in new ventures? A dynamic model and longitudinal exploration", Entrepreneurship Theory and Practice, Vol. 25 No. 3, pp. 37-58.

Park, Y.J. and Park, Y.W. (2018), "Spinoffs versus non-spinoff entrepreneurs exploring post-bubble Japan's entrepreneurial ecosystem", Asia Pacific Journal of Innovation and Entrepreneurship, Vol. 12 No. 2, pp. 146-164.

Pfeffer, J. and Salancik, G.R. (1978), The External Control of Organizations, Harper and Row, New York, NY.

Robinson, S. and Stubberud, H.A. (2009), "Business incubator explanations: networking and gender differences", Management Review: An International Journal, Vol. 4 No. 2, pp. 4-28.

Shane, S. (2000), "Prior knowledge and the discovery of entrepreneurial opportunities", Organization Science, Vol. 11 No. 4, pp. 448-469.

Shane, S. and Khurana, R. (2003), "Bringing individuals back in: the effects of career experience on new firm founding", Industrial and Corporate Change, Vol. 12 No. 3, pp. 519-543.

Shane, S. and Venkataraman, S. (2000), "The promise of entrepreneurship as a field of research", Academy of Management Review, Vol. 25 No. 1, pp. 217-226.

Stuart, R.W. and Abetti, P.A. (1990), "Impact of entrepreneurial and management experience on early performance", Journal of Business Venturing, Vol. 5 No. 3, pp. 151-162.

Ucbasaran, D., Westhead, P. and Wright, M. (2006), Habitual Entrepreneurs, Edward Elgar Publishing.

Ucbasaran, D., Westhead, P. and Wright, M. (2009), "The extent and nature of opportunity identification by experienced entrepreneurs", Journal of Business Venturing, Vol. 24 No. 2, pp. 99-115.

Ucbasaran, D., Westhead, P., Wright, M. and Binks, M. (2003), "Does entrepreneurial experience influence opportunity identification?", The Journal of Private Equity, Vol. 7 No. 1, pp. 7-14.

Udimal, T.B., Jincai, Z. and Gumah, I.A. (2019), "Dynamics in rural entrepreneurship - the role of knowledge acquisition, entrepreneurial orientation, and emotional intelligence in network reliance and performance relationship", Asia Pacific Journal of Innovation and Entrepreneurship, Vol. 13 No. 2, pp. 247-262.

Vaillant, Y. and Lafuente, E. (2019), "Entrepreneurial experience and the innovativeness of serial entrepreneurs”, Management Decision, Vol. 57 No. 11, pp. 2869-2889.

Vandenbroucke, E., Knockaert, M. and Ucbasaran, D. (2016), "Outside board human capital and early stage high-tech firm performance", Entrepreneurship Theory and Practice, Vol. 40 No. 4, pp. 759-779.

Westhead, P. and Wright, M. (1998), "Novice, portfolio, and serial founders: are they different?", Journal of Business Venturing, Vol. 13 No. 3, pp. 173-204.

Westhead, P., Ucbasaran, D. and Wright, M. (2005), "Decisions, actions, and performance: do novice, serial, and portfolio entrepreneurs differ?", Journal of Small Business Management, Vol. 43 No. 4, pp. 393-417. 
APJIE 14,3

Westhead, P., Ucbasaran, D., Wright, M. and Binks, M. (2005), "Novice, serial and portfolio entrepreneur behaviour and contributions", Small Business Economics, Vol. 25 No. 2, pp. 109-132.

Yermack, D. (1996), "Higher market valuation of companies with a small board of directors", Journal of Financial Economics, Vol. 40 No. 2, pp. 185-211.

\section{Further reading}

Hillman, A.J., Cannella, A.A. and Paetzold, R.L. (2000), "The resource dependence role of corporate directors: strategic adaptation of board composition in response to environmental change", Journal of Management Studies, Vol. 37 No. 2, pp. 235-256.

\section{Corresponding author}

Laura Gasiorowski can be contacted at: lgasio@udel.edu

For instructions on how to order reprints of this article, please visit our website: www.emeraldgrouppublishing.com/licensing/reprints.htm

Or contact us for further details: permissions@emeraldinsight.com 